\title{
Tissue-Engineered Devices in Cardiovascular Surgery
}

\author{
C. Klopscha, b G. Steinhoffa, b

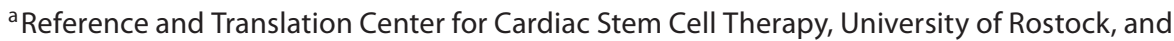 \\ ${ }^{b}$ Department of Cardiac Surgery, Heart Center Rostock, University of Rostock, Rostock, Germany
}

\section{Key Words}

Decellularized graft $\cdot$ In vitro and in vivo cellularization •

Endothelialization • Vascularization • Artificial and

biological prostheses $\cdot$ Antigenicity

\begin{abstract}
Manufacturing life-long functional cardiovascular (CV) implants is the ultimate goal for researchers and clinicians in the cardiothoracic field. Tissue engineering (TE) is an opportunity to create ideal prostheses that are vital, growing, adaptive, autologous and functionally optimally performing. Today, initial translation from basic science to first clinical trials has begun. The article depicts the state of the art in $\mathrm{TE}$ techniques for $\mathrm{CV}$ products and describes milestones in the ongoing development of tissue-engineered myocardial, valvular and vascular devices from an experimental and clinical point of view. Artificial CV implants still reveal remarkable limitations but promising advances regarding optimal structural design, the prevention of intimal hyperplasia and the reduction of antigenicity and thrombogenicity. Where applicable, the implantation of vascularized autografts should still be preferred. Apart from that, decellularized allogen bioprostheses currently represent most promising matrix scaffolds that can be autologously cellularized in vitro prior to or in vivo after implantation. Capable biologic alter-
\end{abstract}

natives have been described like the decellularized porcine small intestinal submucosa. Rising evidence suggests that in vitro endothelialization might be the minimal requirement for improved long-term results of biological tissue-engineered CV grafts.

Copyright ๑ 2012 S. Karger AG, Basel

\section{Introduction}

Functional reconstruction and replacement of cardiovascular $(\mathrm{CV})$ structures with the means of tissue engineering (TE) is evolving dynamically. The implantation of ideal prostheses has not been described yet. However, TE could enable the generation of vital, growing, adaptive, autologous and functionally competent CV tissues and organs. Understanding the roles and interactions of parenchymal, stromal and stem cells with highly defined biologic and artificial matrices and scaffolds will smoothen the way to success [1]. Herein, translational approaches facilitate bridging the latest results from laboratory benches to surgical theaters. The article describes current advances in TE of myocardial, valvular and vascular products and estimates their availability and feasibility for the clinical surgeon. 


\section{Developments in Cell-Plus-Matrix Constructs}

At present, TE predominately applies three-dimensional cell-plus-matrix constructs. Biological or artificial matrix structures for CV implants must demonstrate specific biochemical and biomechanical properties for sufficient long-term performance. Decellularized allografts and xenografts seem to be excellent scaffolds for recellularization-based TE and promise optimal postsurgical results after orthotopic implantation [2]. A possible biological alternative is the extracellular matrix from porcine small intestinal submucosa for tissue-engineered $\mathrm{CV}$ devices [3, 4]. First artificial matrices used for TE were manufactured of nonbiodegradable polytetrafluoroethylene or Dacron [5, 6]. Advancing for biodegradable prostheses followed the idea of generating grafts that could primarily replace the function of a diseased tissue and will secondly be replaced completely by autologous and functional reconstructed tissue (fig. 1). Consequently, growing and adaptive grafts could be manufactured preventing reoperations at least in children. Today, various biodegradable scaffold materials are available and can be combined like collagen, fibrin, gelatin, alginate, polyglycolide, polylactide, polyhydroxybutyrate, polydioxanone, polyesteramides, polyurethane and polycaprolactone beside others $[7,8]$. The fabrication of artificial matrices requires strong regulation regarding elastic modulus, tensile strength and stability according to the widely varying in vivo demands on the final implants. Therefore, textile reinforcement strategies like controlled fiber alignment [9], gamma radiation [10], photo- or thermal-crosslinking [11, 12], multipolymer composites [13], fibrils at different size scales [14], multiple interconnected layers [15, 16], selective laser sintering [17] or particle leaching [18] represent important techniques for the TE of artificial grafts. However, one must consider that beside biomechanical properties the micro- and nanostructures are particularly important for engraftment. Consequently, reducing the porosity will strengthen the graft but reduce its capacity for engraftment [19].

The biocompatibility and long-term performance of biological and artificial devices, in particular xenografts and artificial small-diameter tubular grafts, are clearly limited due to complications like degradation, fibrosis, calcification, immunologic rejection, infection and/or thrombogenicity [20-22]. As a consequence, special decellularization processing was recommended for biological grafts improving their immunogenicity and engraftment $[23,24]$. Today, autologous cellularization of $\mathrm{TE}$ products is feasible for various multipotent stem and dif-

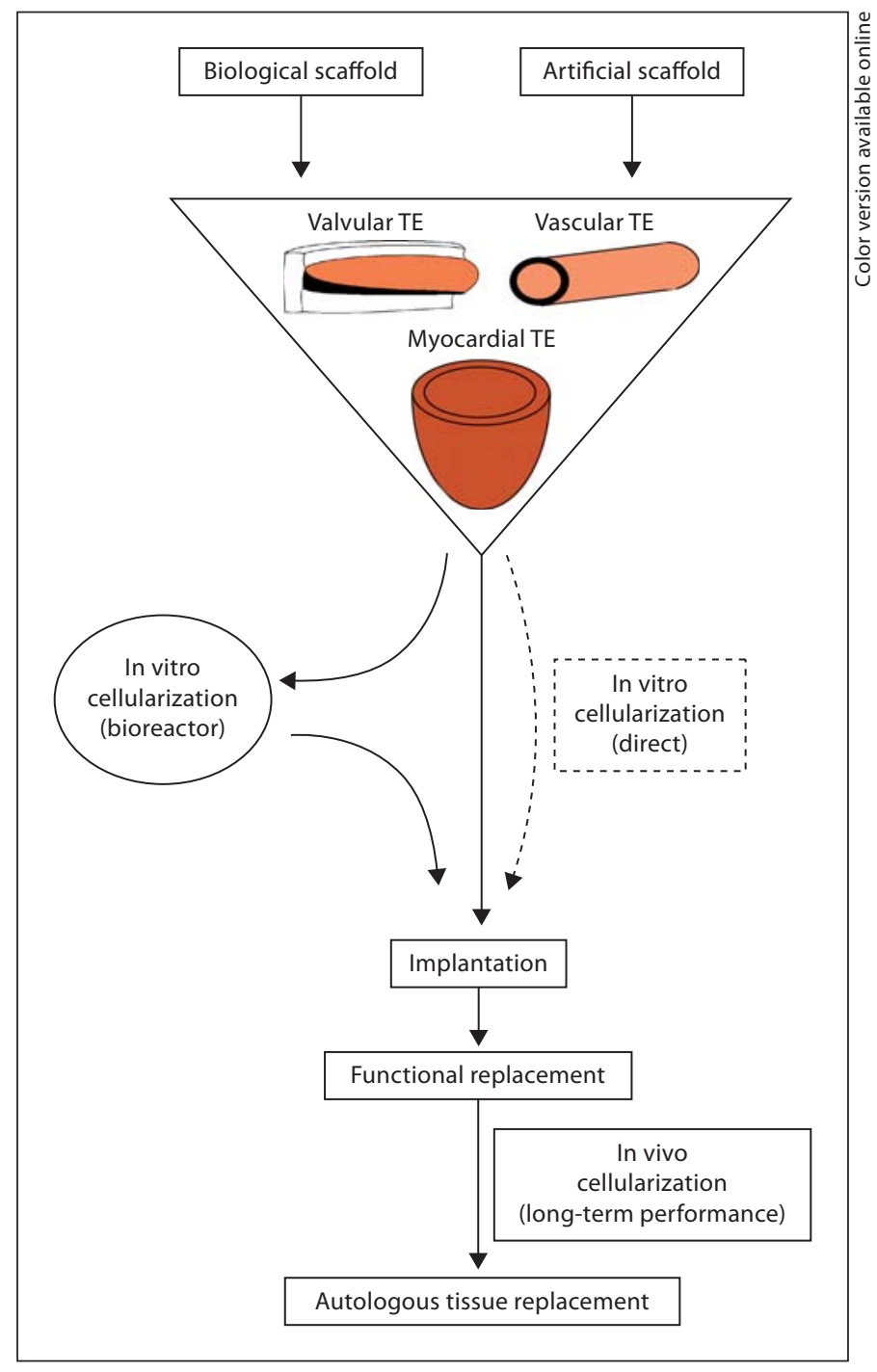

Fig. 1. General principles in cardiovascular TE. The scheme illustrates the processing of vascular, valvular and myocardial grafts generated from biological and artificial scaffolds and cellularized by in vitro bioreactor-driven conditionings, direct tableside coating strategies or in vivo engraftment following implantation. Consequently, these TE products could replace primarily the function of a diseased structure and secondly the complete structure by autologous and functional reconstructed tissue.

ferentiated mature cell types [1]. It was postulated that endothelial cell seeding could eliminate thrombogenicity of tissue-engineered CV implants [25]. For superior endothelial engraftment, different in vitro cellularization techniques were introduced including bioreactor-driven conditionings [26-29] or direct coating strategies [30]. For the enhancement of the angiogenic microenviron- 
Table 1. Milestones in the development of vascular TE devices

\begin{tabular}{|c|c|c|c|c|c|c|}
\hline $\begin{array}{l}\text { Device } \\
\text { type }\end{array}$ & Graft origin/scaffold & In vitro cellularization & Functionalization & Implantation & Availability & Reference \\
\hline \multirow[t]{2}{*}{ Biologic } & $\begin{array}{l}\text { Porcine detergent } \\
\text { decellularized aorta }\end{array}$ & $\begin{array}{l}\text { Scaffold cell seeding and } \\
\text { bioreactor conditioning }\end{array}$ & None & Orthotopic in vivo & Experimental & $\begin{array}{l}\text { Bader et al. [27] } \\
\text { Teebken et al. [37] }\end{array}$ \\
\hline & Hemodialysis shunt graft & $\begin{array}{l}\text { Autologous in vitro } \\
\text { grown }\end{array}$ & None & $\begin{array}{l}\text { Arteriovenous shunt } \\
\text { in vivo }\end{array}$ & Clinical study & McAllister et al. [39] \\
\hline \multirow[t]{4}{*}{ Artificial } & $\begin{array}{l}\text { Small-diameter } \\
\text { polycaprolactone }\end{array}$ & None & +/- Paclitaxel-eluting & Rat aorta in vivo & Experimental & $\begin{array}{l}\text { Innocente et al. [35] } \\
\text { Pektok et al. [41] }\end{array}$ \\
\hline & ePTFE graft & Scaffold cell seeding & RGD-peptide coating & In vitro analysis & Experimental & Walluschek et al. [29] \\
\hline & Different polymer grafts & None & None & $\begin{array}{l}\text { Porcine coronary } \\
\text { artery in vivo }\end{array}$ & Experimental & $\begin{array}{l}\text { van der Giessen et al. } \\
\text { [22] }\end{array}$ \\
\hline & $\begin{array}{l}\text { Copolymer } \\
\text { (polycaprolactone, } \\
\text { polylactid, polyglycolic acid) }\end{array}$ & $\begin{array}{l}\text { Scaffold cell seeding and } \\
\text { bioreactor conditioning }\end{array}$ & None & $\begin{array}{l}\text { Pulmonary artery, } \\
\text { cavopulmonary } \\
\text { conduit in vivo }\end{array}$ & Clinical study & $\begin{array}{l}\text { Shin'oka et al. [38] } \\
\text { Hibino et al. [42] }\end{array}$ \\
\hline
\end{tabular}

The table summarizes highly relevant advances in experimental and clinical research developing tissue-engineered vascular devices with respect to graft origin, cellularization technique and possible implantation sides.

ment, autologous biomaterials like fibrin could be used in cell-plus-matrix molded or coated CV devices [30, 31]. As an alternative, tissue-engineered $\mathrm{CV}$ implants could be cellularized in vivo (i.e. in situ) with possible regulation by cytokines or special surface coating strategies $[29,32$, 33]. The incorporation of local drug delivery systems into the matrix of a graft could remarkably modulate in vivo stem cell recruitment and the recellularization process [32]. Intense investigation is currently ongoing in order to create smart TE products that are stimulus-sensitive and therefore adaptive to multiple microenvironmental situations.

\section{Vascular Tissue Engineering}

The transplantation of arterial and venous autografts still represents the gold standard for vascular replacement of small-diameter vessels like coronary arteries. Dacron and polytetrafluoroethylene prostheses, xenografts or allograft are commonly used for the reconstruction of larger vessels like the ascending aorta, the pulmonary trunk and arteries, the aortic arch and its branch vessels. However, these artificial or xenogenic vascular grafts show unsatisfactory long-term results with lower prosthetic diameters (below $6 \mathrm{~mm}$ ) because of intimal hyperplasia and other above-mentioned reasons [20-22]. Apart from that, the availability of autografts can be limited due to former surgery or vascular disease and harvesting of autografts will definitely increase the surgical trauma. Consequently, TE concepts aim at the generation of anytime-available, adaptive, immunologically accepted and functionally long-term competent prostheses [34]. Three-dimensional artificial or biologic cell-free matrices could be tissue-engineered employing in vitro or in vivo cellularization reducing long-term complications especially in small-diameter artificial prostheses [26, 30, $32,35]$ (table 1). These cellularization technologies demonstrate the potential to promote complete autologous replacement of implanted vascular grafts with cellular organization and structural integrity of a native vessel. First in-man trials are currently ongoing [36-39].

The highly precise fabrication of artificial tubular constructs can be accomplished by computer-controlled rapid prototyping or electrospinning beside other methods. Biomechanical, biochemical as well as micro- and nanostructures (e.g. porosity) can be regulated [10, 40]. However, biodegradable vascular prostheses are currently not yet commercially available for the clinical surgeon because of long-term insufficiency [34]. Polymers with prolonged in vivo biodegradation time like polycaprolactone demonstrated at least promising results. Six months after experimental in vivo transplantation into the arterial circulation small-diameter vascular polycaprolactone grafts were found still functional and completely engrafted with autologous endothelialization [41]. More recently, advanced approaches even introduced biodegradable polymer-based vascular grafts into the clinical practice by implanting extracardiac cavopulmonary conduits made from polymer sheets in children [42]. 
Table 2. Milestones in the development of valvular TE devices

\begin{tabular}{|c|c|c|c|c|c|c|}
\hline $\begin{array}{l}\text { Device } \\
\text { type }\end{array}$ & Graft origin/scaffold & $\begin{array}{l}\text { In vitro } \\
\text { cellularization }\end{array}$ & $\begin{array}{l}\text { Function- } \\
\text { alization }\end{array}$ & $\begin{array}{l}\text { Implan- } \\
\text { tation }\end{array}$ & Availability & Reference \\
\hline \multirow[t]{8}{*}{ Biologic } & $\begin{array}{l}\text { Porcine cryopreserved } \\
\text { decellularized pulmonary graft }\end{array}$ & $\begin{array}{l}\text { Direct cell-plus-matrix } \\
\text { scaffold coating }\end{array}$ & None & $\begin{array}{l}\text { In vitro } \\
\text { analysis }\end{array}$ & Experimental & Kaminski et al. [30] \\
\hline & $\begin{array}{l}\text { Porcine fibrin hydrogel-based } \\
\text { valvular grafts }\end{array}$ & $\begin{array}{l}\text { Complete cell-plus-matrix } \\
\text { molding and bioreactor } \\
\text { conditioning }\end{array}$ & None & $\begin{array}{l}\text { Pulmonary } \\
\text { graft in vivo }\end{array}$ & Experimental & Flanagan et al. [31] \\
\hline & $\begin{array}{l}\text { Porcine pulmonary graft coated } \\
\text { with small intestinal submucosa } \\
\text { for pulmonary valved stent }\end{array}$ & $\begin{array}{l}\text { Scaffold cell seeding and } \\
\text { bioreactor conditioning }\end{array}$ & None & $\begin{array}{l}\text { Orthotopic } \\
\text { in vivo }\end{array}$ & Experimental & Lutter et al. [4] \\
\hline & $\begin{array}{l}\text { Detergent decellularized aortic and } \\
\text { pulmonary grafts (porcine, sheep) }\end{array}$ & $\begin{array}{l}\text { Scaffold cell seeding and } \\
\text { bioreactor conditioning }\end{array}$ & None & $\begin{array}{l}\text { Orthotopic } \\
\text { in vivo }\end{array}$ & Experimental & $\begin{array}{l}\text { Rieder et al. [23] } \\
\text { Kasimir et al. [24, 25] } \\
\text { Bader et al. [26] } \\
\text { Steinhoff et al. [33] } \\
\text { Lopes et al. [55] }\end{array}$ \\
\hline & $\begin{array}{l}\text { Titanium-coated glutaraldehyde- } \\
\text { fixed xenografts }\end{array}$ & None & $\begin{array}{l}\text { Titanium- } \\
\text { coating }\end{array}$ & $\begin{array}{l}\text { In vitro } \\
\text { analysis }\end{array}$ & Experimental & Guldner et al. [62] \\
\hline & $\begin{array}{l}\text { Human detergent decellularized } \\
\text { pulmonary graft }\end{array}$ & $\begin{array}{l}\text { Scaffold cell seeding and } \\
\text { bioreactor conditioning }\end{array}$ & None & $\begin{array}{l}\text { Orthotopic } \\
\text { in vivo }\end{array}$ & Clinical study & Cebotari et al. [45] \\
\hline & $\begin{array}{l}\text { Human detergent decellularized } \\
\text { aortic graft }\end{array}$ & None & None & $\begin{array}{l}\text { Orthotopic } \\
\text { in vivo }\end{array}$ & $\begin{array}{l}\text { Experimental/ } \\
\text { clinical study }\end{array}$ & $\begin{array}{l}\text { da Costa et al. [56] (clinical) } \\
\text { Akhyari et al. [61] } \\
\text { (experimental) }\end{array}$ \\
\hline & $\begin{array}{l}\text { Human cryopreserved } \\
\text { decellularized pulmonary graft }\end{array}$ & None & None & $\begin{array}{l}\text { Orthotopic } \\
\text { in vivo }\end{array}$ & Clinical study & $\begin{array}{l}\text { Brown et al. [50] } \\
\text { Konuma et al. [51] }\end{array}$ \\
\hline \multirow[t]{2}{*}{ Artificial } & Polycaprolactone three-leaflet valve & None & None & $\begin{array}{l}\text { In vitro } \\
\text { functional } \\
\text { assessment }\end{array}$ & Experimental & Del Gaudio et al. [46] \\
\hline & Polymer (SIBS) three-leaflet valve & None & None & In vivo & Experimental & Wang et al. [49] \\
\hline
\end{tabular}

The table summarizes highly relevant advances in experimental and clinical research developing tissue-engineered valvular devices with respect to graft origin, cellularization technique and possible implantation sides.

\section{Valvular Tissue Engineering}

Long-term results after heart valve replacement using allogenic and xenogenic biological heart valves are influenced by tissue degeneration, calcification and infection. Unless optimal hemodynamics valvular allografts and xenografts as well as vital autografts in Ross procedures even show limited late postsurgical outcomes [2, 43, 44]. TE may be used to generate valve tissue undergoing vital regeneration from autologous cell source and tissue adaptation including endothelial recovery and infectious compatibility. In particular, pediatric and younger patients could be treated with vital, growing and adaptive implants preventing reoperations [2]. In accordance with vascular TE, valvular TE requires a three-dimensional biologic or artificial matrix scaffold as well as in vitro or in vivo cellularization $[4,26,30,45]$. In addition, there are necessities mainly attributed to valvular TE that have not yet been accomplished today. The regional different load conditions at a performing semilunar valve set strong demands to the fabrication of an optimal TE valve [46]. Soft but sufficient valve closure requires a balance of structural stability, tensile strength and elastic modulus for both the three-dimensional scaffold as well as the single polymer fibers. Moreover, the creation of vital TE valves most probably needs a highly dynamic processing with the maintenance of special active signals $[47,48]$. A part from that, polymer biodegradation (of implanted biodegradable valves) and in vivo restoration of a long-term functional vital valve must run simultaneously and equally efficient [49].

Decellularized allografts and xenografts seem almost optimal scaffolds for valvular TE [30, 50, 51] (table 2). However, different decellularization protocols show varying efficiency for decellularization, recellularization capacity and removal of antigenicity [20, 23, 24]. The cryopreserved decellularized valves show a highly preserved extracellular matrix structure resulting in adequate midterm hemodynamic performance of allografts 
Table 3. Milestones in the development of myocardial TE devices

\begin{tabular}{|c|c|c|c|c|c|c|}
\hline $\begin{array}{l}\text { Device } \\
\text { type }\end{array}$ & Graft origin/scaffold & In vitro cellularization & $\begin{array}{l}\text { Function- } \\
\text { alization }\end{array}$ & Implantation & Availability & Reference \\
\hline \multirow[t]{7}{*}{ Biologic } & $\begin{array}{l}\text { Porcine extracellular matrix from } \\
\text { urinary bladder }\end{array}$ & None & $\begin{array}{l}+/ \text { - growth } \\
\text { factors }\end{array}$ & $\begin{array}{l}\text { Myocardial patch in } \\
\text { vivo }\end{array}$ & Experimental & $\begin{array}{l}\text { Badylak et al. [64] } \\
\text { Ota et al. [66] }\end{array}$ \\
\hline & Small intestinal submucosa & $\begin{array}{l}\text { Scaffold cell seeding and } \\
\text { in vitro cultivation }\end{array}$ & None & $\begin{array}{l}\text { Myocardial patch in } \\
\text { vivo }\end{array}$ & Experimental & Tan et al. [3] \\
\hline & $\begin{array}{l}\text { Decellularized bovine extracellular } \\
\text { matrix from pericardium }\end{array}$ & +/- scaffold cell seeding & $\begin{array}{l}+/- \text { growth } \\
\text { factors }\end{array}$ & $\begin{array}{l}\text { Myocardial patch in } \\
\text { vivo }\end{array}$ & Experimental & Chang et al. $[65,67]$ \\
\hline & $\begin{array}{l}\text { Vascularized grafts (small } \\
\text { intestinum submucosa, gastric } \\
\text { submucosa) }\end{array}$ & None & None & $\begin{array}{l}\text { Myocardial patch in } \\
\text { vivo }\end{array}$ & Experimental & $\begin{array}{l}\text { Tudorache et al. [69] } \\
\text { Ruel et al. [70] }\end{array}$ \\
\hline & $\begin{array}{l}\text { Skeletal muscle } \\
\text { (M. latissimus dorsi) grafting }\end{array}$ & None & None & $\begin{array}{l}\text { Ventricle (re-) } \\
\text { construction in vivo }\end{array}$ & Experimental & Acker et al. [72] \\
\hline & Porcine decellularized myocardial & $\begin{array}{l}+/- \text { scaffold cell seeding } \\
\text { and in vitro cultivation }\end{array}$ & None & $\begin{array}{l}\text { Myocardial patches } \\
\text { and pouches in vivo }\end{array}$ & Experimental & $\begin{array}{l}\text { Wang et al. [75] } \\
\text { Yildirim et al. [76] } \\
\text { Zimmermann et al. [77] }\end{array}$ \\
\hline & Combined autografting & None & None & $\begin{array}{l}\text { Cardiomyoplasty } \\
\text { in vivo }\end{array}$ & Case study & Taheri et al. [74] \\
\hline Artificial & Polyester urethane urea patch & Direct laser cell printing & None & $\begin{array}{l}\text { Myocardial patch in } \\
\text { vivo }\end{array}$ & Experimental & Gaebel et al. [68] \\
\hline
\end{tabular}

The table summarizes highly relevant advances in experimental and clinical research developing tissue-engineered myocardial devices with respect to graft origin, cellularization technique and possible implantation sides.

that is even superior to conventional allografts $[50,51]$. These cryopreserved decellularized allografts are commercially available anytime [51] but the overall supply is limited due to the donor dependency. Unfortunately, these valves revealed a seemingly low recellularization capacity complicating in vitro and in vivo $\mathrm{TE}[30,52,53]$. Moreover, several studies documented a remarkable number of residing donor cells and immunogenic epitopes like alpha-Gal that had led to strong foreign body reactions in xenografts $[20,24,54]$. In contrast, detergentmediated decellularized valves seem less immunogenic and more engraftable while maintaining adequate midterm hemodynamic performance even in aortic valve position $[50,51,55,56]$. By applying TE, these allografts and possibly xenografts might become optimal substitutes for a diseased native valve [57].

However, the feasibility and necessity of in vitro recellularization of decellularized valves is currently in question. In vitro preconditioning in bioreactors requires several weeks of complex laboratory processing with contamination risks and high costs [58]. Direct cell-coating strategies performed tableside during valve replacement surgeries seem more simply applicable, anytime available and adaptive to individual specialties [30]. Apart from that, the availability of autologous cells for valvular in vitro cellularization is critical especially in pediatric cases.
The importance of umbilical cord-derived endothelial cells as well as stem cells has to be emphasized for these special patients [1]. Moreover, valvular cells seem highly differentiated. Consequently, the appropriateness of using endothelial and interstitial cells from peripheral vessels for valvular TE is also questioned [59]. Regarding the necessity for in vitro cellularization prior to implantation, the majority of studies support the need for superficial endothelialization of decellularized valves that might improve long-term results of grafts at least in pulmonary valve position $[25,60]$. On the contrary, the more demanding interstitial in vitro cellularization might be dispensable for the prevention of explained long-term complications [61].

Promising alternatives are exclusively in vitro manufactured autologous cell-plus-matrix molded valves that have already been tested in vivo in a pioneer study [31]. However, bioreactor conditioning is intensely time consuming and the concept is currently not yet applicable for clinical use. Another biologic opportunity might be the construction of valves with the decellularized matrix from small intestinal submucosa. These xenografts would be commercially available anytime and seemingly demonstrate high in vivo recellularization potential $[3,4]$. Apart from that, coating of conventional glutaraldehydefixed xenografts with titanium might accelerate in vivo endothelialization and improve long-term outcomes [62]. 


\section{Myocardial Tissue Engineering}

The bioartificial generation of myocardial tissues similarly employs artificial or biologic cell-free matrices that will be cellularized in vitro or in vivo. In contrast to other TE products, myocardial prostheses demonstrate special requirements like a synchronized activation and contraction of its cardiomyocytes, adequate mechanical strength, elastic modulus and force development as well as electrophysiological integration after in vivo implantation. Apart from that, cell-plus-matrix myocardial TE grafts (thicker than $100 \mu \mathrm{m}$ ) need vascularization for the survival of cardiac myocytes [63].

Various biological substrates like the urinary bladder, the small intestinal submucosa or the pericardium have been tested (table 3). These cell-free matrices were vascularized and recellularized in vivo with cardiomyocytes, myofibroblasts and smooth muscle cells beside others. Some of the in vivo tissue-engineered prostheses even demonstrated remarkable contractility $[3,64,65]$. The addition of growth factors and/or stem cells could further accelerate the recellularization process $[66,67]$. In our group, we found that precisely directed cell seeding on artificial matrices with the use of laser cell printing ('endothelial network printing') could faster facilitate a functional connection of the grafts' preformed microvasculature to the host's microvasculature [68]. Apart from that, the use of vascularized autotransplants from small intestinal or gastric submucosa, peritoneum or omentum enables the application of transplants with immediate sufficient vascularization. At present, they have been predominately tested experimentally as epicardial patches for the repair of ischemic myocardium [69-71]. Prostheses from skeletal muscle seemingly still demonstrate the greatest potency for myocardial support or replacement [72]. However, the transdifferentiation potential and electrical coupling of myoblasts and myocytes to cardiomyocytes is limited [73]. Clinically, pioneer surgeons have treated severe heart failure patients with combined biological TE products [74].

A decellularized heart muscle logically seems as the most favorable biomatrix for myocardial TE products. The macroscopic and microscopic three-dimensionality is preserved and cell-matrix interactions after autologous recellularization could work optimally [75]. However, the limited availability of allografts, the immunogenicity of xenografts as well as the difficulties in isolation and cultivation of an adequate number of autologous contractile cells currently impede clinical translation. Nevertheless, highly advanced approaches experimentally tested in vi- tro tissue-engineered myocardial pouches for ventricular assist devices following physical conditioning in bioreactors [76]. This research group even showed efficient electrical coupling of tissue-engineered cardiomyocyte cell sheets after pericardial transplantation to the heart [77]. These encouraging results will hopefully soon find translation into clinical practice for the regeneration and replacement of diseased myocardium.

\section{Conclusion}

Clinical translation has begun in cardiac surgery. TE promises the creation of vital, growing, adaptive, autologous and functionally optimally performing CV implants. However, basic technology and clinical translation is still in an initial phase. Small-diameter vascular grafts, lifelong functional valvular grafts without the need for anticoagulation and sufficiently force-developing myocardial grafts will not be clinically available in a short-term development. The article cites landmark studies in the evolution of TE in the CV field. Artificial grafts still show several limitations but remarkable improvements in structural design, engraftment and hemocompatibility. Apart from that, techniques for vascularized autograft transplantation have been described. If autografting is not applicable or feasible, decellularized allogen bioprostheses can be applied that are recellularized in vitro or in vivo. Promising biological alternatives have been portrayed like the decellularized small intestinal submucosa. Noteworthy, in vitro endothelialization might be obligatory for the improvement of long-term results of decellularized biological transplants. The importance of regulating in vivo cellularization by active signals via biofunctionalization is under intense investigation.

\section{Acknowledgements}

This work was supported by the German Ministry of Education (BMBF; Germany, Berlin; funding indicator $0312138 \mathrm{~A}$ ), the Ministry of Economy (Mecklenburg-West Pommerania, Schwerin; funding indicator RTC V220-630-08-TFMV-F/S-035) as well as the German Research Foundation (DFG; Germany, Berlin; funding indicator SFB TR37, TPA4) and REBIRTH Cluster of Excellence (Exc62/1).

\section{Disclosure Statement}

None of the authors have a conflict of interest to declare. 


\section{References}

$\checkmark 1$ Klopsch C, Donndorf P, Kaminski A, Ma N, Steinhoff G: Cell sources for cardiovascular tissue engineering. Chirurg 2011;82:295302 .

$\checkmark 2$ Mayer JE Jr: In search of the ideal valve replacement device. J Thorac Cardiovasc Surg 2001;122:8-9.

\3 Tan MY, Zhi W, Wei RQ, Huang YC, Zhou KP, Tan B, Deng L, Luo JC, Li XQ, Xie HQ, Yang ZM: Repair of infarcted myocardium using mesenchymal stem cell seeded small intestinal submucosa in rabbits. Biomaterials 2009;30:3234-3240.

4 Lutter G, Metzner A, Jahnke T, Bombien R, Boldt J, Iino K, Cremer J, Stock UA: Percutaneous tissue-engineered pulmonary valved stent implantation. Ann Thorac Surg 2010; 89:259-263.

5 Herring M, Gardner A, Glover J: Seeding endothelium onto canine arterial prostheses. The effects of graft design. Arch Surg 1979; 114:679-682.

6 Graham LM, Burkel WE, Ford JW, Vinter DW, Kahn RH, Stanley JC: Expanded polytetrafluoroethylene vascular prostheses seeded with enzymatically derived and cultured canine endothelial cells. Surgery 1982; 91:550-559.

$\checkmark 7$ Riha GM, Lin PH, Lumsden AB, Yao Q, Chen C: Review: application of stem cells for vascular tissue engineering. Tissue Eng 2005;11:1535-1552.

$>8$ Bölgen N, Menceloğlu YZ, Acatay K, Vargel I, Pişkin E: In vitro and in vivo degradation ofnon-woven materials made of poly(epsiloncaprolactone) nanofibers prepared by electrospinning under different conditions. J Biomater Sci Polym Ed 2005;16:1537-1555.

-9 Gaumer J, Prasad A, Lee D, Lannutti J: Structure-function relationships and source-toground distance in electrospun polycaprolactone. Acta Biomater 2009;5:1552-1561.

-10 Nottelet B, Pektok E, Mandracchia D, Tille JC, Walpoth B, Gurny R, Möller M: Factorial design optimization and in vivo feasibility of poly(epsilon-caprolactone)-micro- and nanofiber-based small diameter vascular grafts. J Biomed Mater Res A 2009;89:865-875.

-11 Wang S, Yaszemski MJ, Gruetzmacher JA, Lu L: Photo-crosslinked poly $(\varepsilon$-caprolactone fumarate) networks: roles of crystallinity and crosslinking density in determining mechanical properties. Polymer (Guildf) 2008; 49:5692-5699.

12 Sant S, Khademhosseini A: Fabrication and characterization of tough elastomeric fibrous scaffolds for tissue engineering applications. Conf Proc IEEE Eng Med Biol Soc 2010;2010:3546-3548.

-13 Baker BM, Nerurkar NL, Burdick JA, Elliott DM, Mauck RL: Fabrication and modeling of dynamic multipolymer nanofibrous scaffolds. J Biomech Eng 2009;131:101012.
14 Peroglio M, Gremillard L, Gauthier C, Chazeau L, Verrier S, Alini M, Chevalier J: Mechanical properties and cytocompatibility of poly( $\varepsilon$-caprolactone)-infiltrated biphasic calcium phosphate scaffolds with bimodal pore distribution. Acta Biomater 2010;6:4369-4379.

15 Sarkar S, Isenberg BC, Hodis E, Leach JB, Desai TA, Wong JY: Fabrication of a layered microstructured polycaprolactone construct for 3-D tissue engineering. J Biomater Sci Polym Ed 2008;19:1347-1362.

16 Koch S, Flanagan TC, Sachweh JS, Tanios F, Schnoering H, Deichmann T, Ellä V, Kellomäki M, Gronloh N, Gries T, Tolba R, Schmitz-Rode T, Jockenhoevel S: Fibrinpolylactide-based tissue-engineered vascular graft in the arterial circulation. Biomaterials 2010;31:4731-4739.

17 Eshraghi S, Das S: Mechanical and microstructural properties of polycaprolactone scaffolds with one-dimensional, two-dimensional, and three-dimensional orthogonally oriented porous architectures produced by selective laser sintering. Acta Biomater 2010;6:2467-2476.

18 Lebourg M, Sabater Serra R, Más Estellés J, Hernández Sánchez F, Gómez Ribelles JL, Suay Antón J: Biodegradable polycaprolactone scaffold with controlled porosity obtained by modified particle-leaching technique. J Mater Sci Mater Med 2008;19:20472053.

19 Soliman S, Sant S, Nichol JW, Khabiry M, Traversa E, Khademhosseini A: Controlling the porosity of fibrous scaffolds by modulating the fiber diameter and packing density. J Biomed Mater Res A 2011;96:566-574.

20 Cicha I, Rüffer A, Cesnjevar R, Glöckler M, Agaimy A, Daniel WG, Garlichs CD, Dittrich S: Early obstruction of decellularized xenogenic valves in pediatric patients: in volvement of inflammatory and fibroproliferative processes. Cardiovasc Pathol 2011; 20:222-231.

21 Daly KA, Stewart-Akers AM, Hara H, Ezzelarab M, Long C, Cordero K, Johnson SA, Ayares D, Cooper DK, Badylak SF: Effect of the alphaGal epitope on the response to small intestinal submucosa extracellular matrix in a nonhuman primate model. Tissue Eng Part A 2009;15:3877-3888.

22 van der Giessen WJ, Lincoff AM, Schwartz RS, van Beusekom HM, Serruys PW, Holmes DR Jr, Ellis SG, Topol EJ: Marked inflammatory sequelae to implantation of biodegradable and nonbiodegradable polymers in porcine coronary arteries. Circulation 1996;94: 1690-1697.
23 Rieder E, Kasimir MT, Silberhumer G, Seebacher G, Wolner E, Simon P, Weigel G: Decellularization protocols of porcine heart valves differ importantly in efficiency of cell removal and susceptibility of the matrix to recellularization with human vascular cells. J Thorac Cardiovasc Surg 2004;127:399-405.

24 Kasimir MT, Rieder E, Seebacher G, Wolner E, Weigel G, Simon P: Presence and elimination of the xenoantigen gal (alpha1, 3) gal in tissue-engineered heart valves. Tissue Eng 2005; 11:1274-1280.

-25 Kasimir MT, Weigel G, Sharma J, Rieder E, Seebacher G, Wolner E, Simon P: The decellularized porcine heart valve matrix in tissue engineering: platelet adhesion and activation. Thromb Haemost 2005;94:562-567.

26 Bader A, Schilling T, Teebken OE, Brandes G, Herden T, Steinhoff G, Haverich A: Tissue engineering of heart valves - Human endothelial cell seeding of detergent acellularized porcine valves. Eur J Cardiothorac Surg 1998;14:279-284.

27 Bader A, Steinhoff G, Strobl K, Schilling T, Brandes G, Mertsching H, Tsikas D, Froelich J, Haverich A: Engineering of human vascular aortic tissue based on a xenogeneic starter matrix. Transplantation 2000;70:7-14.

28 Walluscheck KP, Steinhoff G, Haverich A: Endothelial cell seeding of native vascular surfaces. Eur J Vasc Endovasc Surg 1996;11: 290-303.

-29 Walluscheck KP, Steinhoff G, Kelm S, Haverich A: Improved endothelial cell attachment on ePTFE vascular grafts pretreated with synthetic RGD-containing peptides. Eur J Vasc Endovasc Surg 1996;12:321-330.

-30 Kaminski A, Klopsch C, Mark P, Yerebakan C, Donndorf P, Gäbel R, Eisert F, Hasken S, Kreitz S, Jockenhövel S, Ma N, Liebold A, Steinhoff G: Autologous valve replacement CD133+ stem cell-plus-fibrin composite based sprayed cell seeding for intra-operative heart valve tissue engineering. Tissue Eng Part C 2011;17:299-309.

-31 Flanagan TC, Sachweh JS, Frese J, Schnoring H, Gronloh N, Koch S, Tolba RH, SchmitzRode T, Jockenhoevel S: In vivo remodeling and structural characterization of fibrinbased tissue-engineered heart valves in the adult sheep model. Tissue Eng Part A 2009; 15:2965-2976.

$>32$ Ko IK, Ju YM, Chen T, Atala A, Yoo JJ, Lee SJ: Combined systemic and local delivery of stem cell inducing/recruiting factors for in situ tissue regeneration. FASEB J 2012;26: 158-168.

33 Steinhoff G, Stock U, Karim N, Mertsching H, Timke A, Meliss RR, Pethig K, Haverich A, Bader A: Tissue engineering of pulmonary heart valves on allogenic acellular matrix conduits: in vivo restoration of valve tissue. Circulation 2000;102:III50-III55. 
34 Walpoth BH, Möller M: Tissue engineering of vascular prostheses. Chirurg 2011;82:303310.

- 35 Innocente F, Mandracchia D, Pektok E, Nottelet B, Tille JC, de Valence S, Faggian G, Mazzucco A, Kalangos A, Gurny R, Moeller M, Walpoth BH: Paclitaxel-eluting biodegradable synthetic vascular prostheses: a step towards reduction of neointima formation? Circulation 2009;120:S37-S45.

- 36 Niklason LE, Gao J, Abbott WM, Hirschi KK, Houser S, Marini R, Langer R: Functional arteries grown in vitro. Science 1999; 284:489-493.

- 37 Teebken OE, Bader A, Steinhoff G, Haverich A: Tissue engineering of vascular grafts: human cell seeding of decellularised porcine matrix. Eur J Vasc Endovasc Surg 2000;19: 381-386.

- 38 Shin'oka T, Imai Y, Ikada Y: Transplantation of a tissue-engineered pulmonary artery. $\mathrm{N}$ Engl J Med 2001;344:532-533.

- 39 McAllister TN, Maruszewski M, Garrido SA, Wystrychowski W, Dusserre N, Marini A, Zagalski K, Fiorillo A, Avila H, Manglano X, Antonelli J, Kocher A, Zembala M, Cierpka L, de la Fuente LM, L'heureux N: Effectiveness of haemodialysis access with an autologous tissue-engineered vascular graft: a multicentre cohort study. Lancet 2009;373: 1440-1446.

-40 Sobral JM, Caridade SG, Sousa RA, Mano JF, Reis RL: Three-dimensional plotted scaffolds with controlled pore size gradients: effect of scaffold geometry on mechanical performance and cell seeding efficiency. Acta Biomater 2011;7:1009-1018.

41 Pektok E, Nottelet B, Tille JC, Gurny R, Kalangos A, Moeller M, Walpoth BH: Degradation and healing characteristics of small-diameter poly(epsilon-caprolactone) vascular grafts in the rat systemic arterial circulation. Circulation 2008;118:2563-2570.

-42 Hibino N, McGillicuddy E, Matsumura G, Ichihara Y, Naito Y, Breuer C, Shinoka T: Late-term results of tissue-engineered vascular grafts in humans. J Thorac Cardiovasc Surg 2010;139:431-436.

-43 Brown JW, Ruzmetov M, Rodefeld MD, Vijay $\mathrm{P}$, Turrentine MW: Right ventricular outflow tract reconstruction with an allograft conduit in non-Ross patients: risk factors for allograft dysfunction and failure. Ann Thorac Surg 2005;80:655-663.

-44 Frigiola A, Varrica A, Satriano A, Giamberti A, Pomè G, Abella R, Carminati M, Carlucci C, Ranucci M, Surgical and Clinical Outcome REsearch (SCORE) Group: Neoaortic valve and root complex evolution after ross operation in infants, children, and adolescents. Ann Thorac Surg 2010;90:1278-1285.
45 Cebotari S, Lichtenberg A, Tudorache I, Hilfiker A, Mertsching H, Leyh R, Breymann T, Kallenbach K, Maniuc L, Batrinac A, Repin O, Maliga O, Ciubotaru A, Haverich A: Clinical application of tissue engineered human heart valves using autologous progenitor cells. Circulation 2006;114:I132-I137.

46 Del Gaudio C, Bianco A, Grigioni M: Electrospun bioresorbable trileaflet heart valve prosthesis for tissue engineering: in vitro functional assessment of a pulmonary cardiac valve design. Ann Ist Super Sanita 2008,44:178-186.

47 Weston MW, Yoganathan AP: Biosynthetic activity in heart valve leaflets in response to in vitro flow environments. Ann Biomed Eng 2001;29:752-763.

48 Engelmayr GC Jr, Rabkin E, Sutherland FW Schoen FJ, Mayer JE Jr, Sacks MS: The independent role of cyclic flexure in the early in vitro development of an engineered heart valve tissue. Biomaterials 2005;26:175-187.

49 Wang Q, McGoron AJ, Bianco R, Kato Y, Pinchuk L, Schoephoerster RT: In-vivo assessment of a novel polymer (SIBS) trileaflet heart valve. J Heart Valve Dis 2010;19:499_ 505.

50 Brown JW, Elkins RC, Clarke DR, Tweddell JS, Huddleston CB, Doty JR, Fehrenbacher JW, Takkenberg JJ: Performance of the CryoValve SG human decellularized pulmonary valve in 342 patients relative to the conventional CryoValve at a mean follow-up of four years. J Thorac Cardiovasc Surg 2010;139: 339-348.

51 Konuma T, Devaney EJ, Bove EL, Gelehrter S, Hirsch JC, Tavakkol Z, Ohye RG: Performance of CryoValve SG decellularized pulmonary allografts compared with standard cryopreserved allografts. Ann Thorac Surg 2009;88:849-854.

52 Sayk F, Bos I, Schubert U, Wedel T, Sievers $\mathrm{HH}$ : Histopathologic findings in a novel decellularized pulmonary homograft: an autopsy study. Ann Thorac Surg 2005;79:17551758.

53 Simon P, Kasimir MT, Seebacher G, Weigel G, Ullrich R, Salzer-Muhar U, Rieder E, Wolner E: Early failure of the tissue engineered porcine heart valve SYNERGRAFT in pediatric patients. Eur J Cardiothorac Surg 2003;23:1002-1006.

54 Kasimir MT, Rieder E, Seebacher G, Nigisch A, Dekan B, Wolner E, Weigel G, Simon P: Decellularization does not eliminate thrombogenicity and inflammatory stimulation in tissue-engineered porcine heart valves. J Heart Valve Dis 2006;15:278-286.

55 Lopes SA, Costa FD, Paula JB, Dhomen P, Phol F, Vilani R, Roderjan JG, Vieira ED: Decellularized heterografts versus cryopreserved homografts: experimental study in sheep model. Rev Bras Cir Cardiovasc 2009; 24:15-22.
6 da Costa FD, Costa AC, Prestes R, Domanski AC, Balbi EM, Ferreira AD, Lopes SV: The early and midterm function of decellularized aortic valve allografts. Ann Thorac Surg 2010;90:1854-1860.

57 Erdbrügger W, Konertz W, Dohmen PM, Posner S, Ellerbrok H, Brodde OE, Robenek $\mathrm{H}$, Modersohn D, Pruss A, Holinski S, SteinKonertz M, Pauli G: Decellularized xenogenic heart valves reveal remodeling and growth potential in vivo. Tissue Eng 2006; 12:2059-2068.

-58 Pörtner R, Nagel-Heyer S, Goepfert C, Adamietz P, Meenen NM: Bioreactor design for tissue engineering, J Biosci Bioeng 2005; 100 : 235-245

-59 Tan PH, Chan C, Xue SA, Dong R, Ananthesayanan B, Manunta $M$, Kerouedan C, Cheshire NJ, Wolfe JH, Haskard DO, Taylor KM, George AJ: Phenotypic and functional differences between human saphenous vein (HSVEC) and umbilical vein (HUVEC) endothelial cells. Atherosclerosis 2004;173: 171-183.

60 Lichtenberg A, Tudorache I, Cebotari S, Suprunov M, Tudorache G, Goerler H, Park JK, Hilfiker-Kleiner D, Ringes-Lichtenberg S, Karck M, Brandes G, Hilfiker A, Haverich A: Preclinical testing of tissue-engineered heart valves re-endothelialized under simulated physiological conditions. Circulation 2006;114:I559-I565.

61 Akhyari P, Kamiya H, Gwanmesia P, Aubin $H$, Tschierschke R, Hoffmann S, Karck M, Lichtenberg A: In vivo functional performance and structural maturation of decellularised allogenic aortic valves in the subcoronary position. Eur J Cardiothorac Surg 2010;38:539-546.

62 Guldner NW, Jasmund I, Zimmermann H, Heinlein M, Girndt B, Meier V, Flüss F, Rohde D, Gebert A, Sievers HH: Detoxification and endothelialization of glutaraldehydefixed bovine pericardium with titanium coating: a new technology for cardiovascular tissue engineering. Circulation 2009;119: 1653-1660.

63 Lovett M, Lee K, Edwards A, Kaplan DL: Vascularization strategies for tissue engineering. Tissue Eng Part B Rev 2009; 15:353370.

64 Badylak SF, Kochupura PV, Cohen IS, Doronin SV, Saltman AE, Gilbert TW, Kelly DJ, Ignotz RA, Gaudette GR: The use of extracellular matrix as an inductive scaffold for the partial replacement of functional myocardium. Cell Transplant 2006;15:S29-S40.

-65 Chang Y, Lee MH, Liang HC, Hsu CK, Sung HW: Acellular bovine pericardia with distinct porous structures fixed with genipin as an extracellular matrix. Tissue Eng 2004; 10: 881-892. 
-66 Ota T, Gilbert TW, Schwartzman D, McTiernan CF, Kitajima T, Ito Y, Sawa Y, Badylak SF, Zenati MA: A fusion protein of hepatocyte growth factor enhances reconstruction of myocardium in a cardiac patch derived from porcine urinary bladder matrix. J Thorac Cardiovasc Surg 2008;136:1309-1317.

-67 Chang Y, Lai PH, Wei HJ, Lin WW, Chen $\mathrm{CH}$, Hwang SM, Chen SC, Sung HW: Tissue regeneration observed in a basic fibroblast growth factor-loaded porous acellular bovine pericardium populated with mesenchymal stem cells. J Thorac Cardiovasc Surg 2007;134:65-73.

-68 Gaebel R, Ma N, Liu J, Guan J, Koch L, Klopsch C, Gruene M, Toelk A, Wang W, Mark P, Wang F, Chichkov B, Li W, Steinhoff G: Patterning human stem cells and endothelial cells with laser printing for cardiac regeneration. Biomaterials 2011;32:92189230 .
69 Tudorache I, Kostin S, Meyer T, Teebken O, Bara C, Hilfiker A, Haverich A, Cebotari S: Viable vascularized autologous patch for transmural myocardial reconstruction. Eur J Cardiothorac Surg 2009;36:306-311.

70 Ruel MA, Sellke FW, Bianchi C, Khan TA, Faro R, Zhang JP, Cohn WE: Endogenous myocardial angiogenesis and revascularization using a gastric submucosal patch. Ann Thorac Surg 2003;75:1443-1449.

71 Huang W, Zhang D, Millard RW, Wang T, Zhao T, Fan GC, Ashraf A, Xu M, Ashraf M, Wang Y: Gene manipulated peritoneal cell patch repairs infarcted myocardium. J Mol Cell Cardiol 2010;48:702-712.

72 Acker MA, Hammond RL, Mannion JD, Salmons S, Stephenson LW: Skeletal muscle as the potential power source for a cardiovascular pump: assessment in vivo. Science 1987;236:324-327.

73 Menasché P: Skeletal myoblasts as a therapeutic agent. Prog Cardiovasc Dis 2007;50: 7-17.

74 Taheri SA, Ashraf H, Merhige M, Miletich RS, Satchidanand S, Malik C, Naughton J, Zhao Q: Myoangiogenesis after cell patch cardiomyoplasty and omentopexy in a patient with ischemic cardiomyopathy. Tex Heart Inst J 2005;32:598-601.
75 Wang B, Borazjani A, Tahai M, Curry AL, Simionescu DT, Guan J, To F, Elder SH, Liao J: Fabrication of cardiac patch with decellularized porcine myocardial scaffold and bone marrow mononuclear cells. J Biomed Mater Res A 2010;94:1100-1110.

76 Yildirim Y, Naito H, Didié M, Karikkineth BC, Biermann D, Eschenhagen T, Zimmermann WH: Development of a biological ventricular assist device: preliminary data from a small animal model. Circulation 2007; 116:I16-I23.

77 Zimmermann WH, Melnychenko I, Wasmeier G, Didié M, Naito H, Nixdorff $U$, Hess A, Budinsky L, Brune K, Michaelis B, Dhein S, Schwoerer A, Ehmke H, Eschenhagen T: Engineered heart tissue grafts improve systolic and diastolic function in infarcted rat hearts. Nat Med 2006;12:452-458. 